\title{
Creativity and Physics Learning as Product of the Intervention with Conceptual Maps and Gowin's V Diagram
}

\author{
Javier A. Pulgar Neira, Iván R. Sánchez Soto \\ Physics Department, Science Faculty, University of Bio Bio, Concepción, Chile \\ Email: jpulgar@ubiobio.cl; isanchez@ubiobio.cl
}

Received August $28^{\text {th }}, 2013$; revised September $28^{\text {th }}, 2013$; accepted October $5^{\text {th }}, 2013$

\begin{abstract}
Copyright (C 2013 Javier A. Pulgar Neira, Iván R. Sánchez Soto. This is an open access article distributed under the Creative Commons Attribution License, which permits unrestricted use, distribution, and reproduction in any medium, provided the original work is properly cited. In accordance of the Creative Commons Attribution License all Copyrights $(\mathcal{2} 2013$ are reserved for SCIRP and the owner of the intellectual property Javier A. Pulgar Neira, Iván R. Sánchez Soto. All Copyright $(\mathcal{C} 2013$ are guarded by law and by SCIRP as a guardian.
\end{abstract}

\begin{abstract}
This paper shows the impact of a methodological renewal, based on conceptual maps and Gowin's V diagram, in academic performance and creativity of freshman students from Civil Engineering in University of Bio Bio, Concepción, Chile, who participate in subject Physics with me in the modular system. The objective in incorporating both heuristic instruments is to facilitate the reflection of information and problem solving in physics. The study is quasi-experimental with pre-and post-test in the study variables. The results show that the proposed methodological renewal significantly influences academic performance, and in certain categories, is of creativity. The analysis also shows a relation between academic performance and creativity, which would predict the success or fail in physics.
\end{abstract}

Keywords: University Physics; Conceptual Maps; Gowin's V Diagram; Academic Performance and Creativity

\section{Introduction}

The academic success, product of a meaningful learning, is related to the ability to transfer, which is understood as the ability to adapt the material learned to problem situations in different contexts, and also is closely linked to creative features of subjects. Consequently, developing the ability to transfer is made possible by the implementation of methodologies that enhance creativity in students. Therefore, a meaningful learning is embodied in the extent to which the new information is related to prior knowledge of the student, which is achieved through reflection and re-organization of the cognitive structure for who is preparing to learn.

In our context, the physics diagnosis test made by freshman students from UBB shows that only $10 \%$ achieved correctly answer questions related to Vectors, Introduction to Kinematics, and Introduction to Dynamics and Energy. In order to cope with these difficulties in physics knowledge and generate the appropriate changes, we have proposed building a methodological renewal for Physics I course based on the resolution of problems by Gowin's V diagram and conceptual maps. This intervention, built for first-year students in Civil Engineering formation, aims to improve the physics learning and creativity of the students, the latter being of great importance to face future professional challenges. Consequently, this quasi-experimental research pretends to show the impact of the methodological renewal in academic performance and creative thinking.

Instruments as the Gowin's V diagram and conceptual map, are helpful for the manifestation of how subjects understand the information and what meanings are given, because while Gowin's V reveals the links between theories and procedures in the resolution of problems, the map can show relationships and hierarchy of concepts graphically demonstrating a student's conceptual domain, promoting the integration of the content. In this context, it may be noted that the resolution of problems through $\mathrm{V}$ diagrams, and building conceptual maps to address conceptual concerns, guides the student to promoting transfer, creativity and reflection of information, in search of a meaningful learning.

The results obtained by the Interest and Creative Performance Questionnaire (ICPQ) indicate that students submitted to the intervention with conceptual maps and V diagrams do better on academic performance. In addition, there was a significant difference in the scores of the categories of creativity (Various Interests), and an increase in the number of students in the experimental group that achieved scores from low to normal-high in art and writing, confidence and independence and varied interests, being these last not significative.

It can be presented graphically with the dependencies between the various modes in the academic study and the different categories of stimulation of creativity, which students declare. So, it is possible to assert that high scores on certain categories of creativity allow predicting the academic success of students.

\section{Creativity and Meaningful Learning}

To introduce some of the techniques that promote the creative potential in students, you must know some of the definitions that experts have had to build to the concept of creativity. Until recently there was no formal definition of this concept, due to the lack of studies and research on it, and it was not until 
after 1992 that the Royal Academy of Spanish Language does define this concept as: "ability to create, capacity of creation."

However, there are earliest definitions of creativity. The Table 1 summarizes some of the contributions to the creative domain.

Considering the definition of De la Torre (1999), it is complex to enclose the creative process in a single definition. However, the above table allows pointing out that creativity is an inherent mechanism of the human mind and sensitive to problems, which is activated to create original, diverse and flexible solutions or problems, seeking the transformation of the present reality of an individual. To Ausubel et al. (1983) creativity has a cognitive dimension, noting that it begins with simple integrative reconciliations that guide the construction of new concepts, hierarchizing the cognitive structure of the subject and encouraging the development of creative relationships.

The element that allows visualising the connection between creativity and meaningful learning emerges from the definition of the first author and constitutes one of its goals: to transform. It is well known that the evidence of a meaningful learning is related to the ability to adapt (transform) learning to different contextual situations and find solutions without difficulty, understood as the ability to transfer. Donolo and Rinaudo (2008)

Table 1.

Definitions of creativity.

\begin{tabular}{|c|c|}
\hline Author & Definition \\
\hline $\begin{array}{l}\text { Osborn } \\
(1953)\end{array}$ & $\begin{array}{l}\text { "Ability to perform, provide and produce ideas. Conversion } \\
\text { of known elements into something new, thanks to a power- } \\
\text { ful imagination." }\end{array}$ \\
\hline $\begin{array}{l}\text { Mac Kinnon } \\
\quad(1960)\end{array}$ & $\begin{array}{l}\text { "Creativity responds to the capacity to upgrade the creative } \\
\text { individual potential through unique and original patterns." }\end{array}$ \\
\hline $\begin{array}{l}\text { Ausubel } \\
(1963)\end{array}$ & $\begin{array}{l}\text { "The creative personality is that which distinguishes one } \\
\text { individual by the quality and originality uncommon for } \\
\text { their contributions to science, art, politics, etc." }\end{array}$ \\
\hline $\begin{array}{l}\text { Bruner } \\
(1963)\end{array}$ & $\begin{array}{l}\text { "Creativity is an act that produces surprises to the subject, } \\
\text { in the sense that it does not recognize it as a previous pro- } \\
\text { duction." }\end{array}$ \\
\hline $\begin{array}{l}\text { Piaget } \\
(1964)\end{array}$ & $\begin{array}{l}\text { "Creativity is the final form of symbolic play of children, } \\
\text { when is assimilated in his thoughts." }\end{array}$ \\
\hline $\begin{array}{l}\text { Guilford } \\
\text { (1971) }\end{array}$ & $\begin{array}{l}\text { "Capacity or ability to generate alternatives from a given } \\
\text { information, with an emphasis on the variety, quantity } \\
\text { and relevance of the results." }\end{array}$ \\
\hline $\begin{array}{l}\text { Torrance } \\
(1976)\end{array}$ & $\begin{array}{l}\text { "Creativity is the process of becoming sensitive to } \\
\text { problems, deficiencies, gaps in knowledge, overlooked } \\
\text { elements, the lack of harmony etc., To summarize valid } \\
\text { information, to identify possible problems and identify } \\
\text { the invalid items, to find solutions, to make guesses or } \\
\text { formulating hypotheses about the deficiencies, to } \\
\text { examine and test these hypotheses and modify if there's } \\
\text { necessary, refining them and finally communicating the } \\
\text { results." }\end{array}$ \\
\hline $\begin{array}{l}\text { Davis and } \\
\text { Scott }(1992)\end{array}$ & $\begin{array}{l}\text { "Creativity is the result of a combination of processes or } \\
\text { attributes that are new to the creator." }\end{array}$ \\
\hline $\begin{array}{c}\text { López and } \\
\text { Recio (1998) }\end{array}$ & $\begin{array}{l}\text { "Creativity is a style that has the mind to process } \\
\text { information, manifesting through the production and } \\
\text { generation of situations, ideas or objects with a degree of } \\
\text { originality; that style of the mind somehow intended } \\
\text { impact or transform the present reality of the individual." }\end{array}$ \\
\hline $\begin{array}{l}\text { De la Torre } \\
\text { (1999) }\end{array}$ & $\begin{array}{l}\text { "If define is surround a field of ideas with a fence of words, } \\
\text { creativity is like an ocean of ideas overwhelmed by a } \\
\text { continent of words." }\end{array}$ \\
\hline
\end{tabular}

(Taken from Esquivias 2001, pp. 2-7). note that "the process of transferring and using knowledge in new situations requires a creative approach that would allow students to jump from unfamiliar tasks and somewhat unstructured, into new applications with-concepts in different contexts of learning." According to Chroback (2008), creative activity requires knowledge conceptually organized and motivation to promote the development of meaningful learning.

Any student subjected to the process of teaching and learning, must move from a first stage of guided manipulation of the operation criteria, corresponding to how the discipline is taught, to the stage that achieves the transformation of these criteria, as a product of a creative behaviour, which also generates and gives meaning to new problems and solutions. Carpio et al. (2007), notes that creative behaviour cannot be taught, but it can be promoted through enriching how to solve problems, and the diverse type of problems that are raised within an area of study. This sets a continuum between intelligent and creative behaviour, which implies that the subject can be creative as long as that which will be subjected to transformation is present in their cognitive structure, i.e. they have learned previously.

\section{Technique to Stimulate Creativity}

The following techniques seek, according to the experts, to encourage the development of creativity, and transfer. There are certain authors who defend the thesis of an educational practice based on the development of creativity (Torre, 1993; Reyes, 2003; Lopez, 2008), arguing that a creative attitude can face the new, improvise and respond through the transfer of learning. For this reason, the use of creative questions in the teaching and learning process will enrich the contextualization in the study tasks, and thus facilitate the transfer. In the same manner, Torrance (cited by Ausubel, Novak, \& Hanesian, 1983, p. 509) notes to respect unusual questions, as a principle to be considered by teachers to reward creative thinking.

On the other hand, Ausubel, Novak and Hanesian (1983, p. 484) define problem solving as a creative strategy that requires the transformation and reintegration of existing knowledge to adapt towards a goal. One strategy to encourage creative activity in teamwork or problem solving it is "Brainstorming", introduced by Osborn (1953).

In reference to teaching methodologies Chroback (2008) notes that the creative process is diminished when the methods of teaching and assessment promote rote or mechanical learning. Consequently, the teacher's role should be oriented in an in deterministic teaching practice (Silva, 2005), favouring the creation, discovery and training of new concepts, avoiding expressed doubts about the ability of their students to give a solution to problems. This in deterministic teacher must possess, among others, the ability to mediate the learning of content, considered that conceptual structures may change, since the disciplinary knowledge evolves in a nonlinear way, like intelligence. Also, he must possess the ability to generate problems with multiple possible solutions, because the student, rather than learning to solve situations with particular solution, must learn to deal with these (Bell, 2000).

\section{Conceptual Maps and V Diagrams}

An image can be understood as a representational element of the knowledge of the subject from any given issue. For this reason, formal education has had to make use of images in or- 
der to promote the learning to learn. The research of Otero, Greca and Lang da Silveira (2003), shows the motivating function, sometimes pleasant, of certain images in students. While the authors sought to determine the influence of these on academic performance, the results are not clear, because as Perales (2006) said, the use of images per se, fails in enhance learning. In this regard, the author indicates the need to interact with these representations, i.e., subjecting them to analysis, criticism, change, etc., they should not be considered as elements of just contemplation (Perales, 2008).

In this line, it is considered very important the use of tools like Gowin's V, which allows to reveal the epistemological aspects of knowledge production (Moreira, 2006), and the concept map, which plots the level of conceptual integration function of the relations network. Both tools emerge in the educational world to promote meaningful learning (Moreira, 1998, 2007). For this reason, many have been used in educational research, for example, Flores, Knight and Moreira (2009) introduced these two instruments for assessing science laboratory. An experience with concept mapping was performed by Ramirez and Sanabria (2004), to study the impact of this tool in the teaching and learning of a college physics course, achieving a better understanding and integration of concepts, facilitating the construction of knowledge. On the other hand, Garcia, Insausti and Merino (2003), use the V diagram as evaluation mechanism on practical work in physics at university level. Similar is the work of Sanabria, Ramirez and Aspee (2006), who designed an instructional strategy for work in physics laboratories, thanks to which students were able to design methodological approaches for the resolution of experimental situations and identify the theoretical domain that supports them. More recent is the work of Gil and Solano (2011) in which they occupied the epistemological V for solving physical problems, achieving improved student attitudes against physical problems. Another reference lies in the paper by Lopez, Angela and Solano (2011), for learning Newtonian mechanics concepts through computer modelling using $\mathrm{V}$ diagrams. The results of the experiment are summarized as: adequate description and understanding of concepts, evidence of significant learning by analyzing a specific situation-problem, and improvements in disposition towards learning.

\section{Method}

This research is performed through a quasi-experimental design (Cohen and Manion, 1990), which defines two groups (experimental and control), which will apply pre and post-test in each of the study variables: levels of creativity and academic performance. It is noteworthy that the groups involved in the subject Physics I, divided in two modules (I and II) that grouped the contents of Kinematics and Dynamics (I), and Collisions and Roto-translation (II).

Throughout the module I of the course, the experimental group will be using $\mathrm{V}$ diagrams and concept maps to solve problems, while a control group will develop the course by solving problems guides. Table 2 shows the research design.

To measure creativity variables, the instrument will be applied before the start of the course (pre-test), and two months after the end the intervention (post-test). The determination of academic performance will occur after the intervention, i.e. after the end of module I.
Table 2.

Study design.

\begin{tabular}{|c|c|c|c|}
\hline Groups & Pre-test & Treatment & Post-test \\
\hline Experimental & $\mathrm{O}_{1}$ & $\mathrm{~T}_{1}$ & $\mathrm{O}_{1}^{\prime}$ y $\mathrm{O}_{2}^{\prime}$ \\
\hline Control & $\mathrm{O}_{1}$ & $\mathrm{~T}_{2}$ & $\mathrm{O}_{1}^{\prime}$ y $\mathrm{O}_{2}^{\prime}$ \\
\hline
\end{tabular}

where:

- $\mathrm{O}_{1}$ y $\mathrm{O}_{1}^{\prime}$ : Test of creative capacities.

$-\mathrm{O}_{2}^{\prime}$ : Exam.

$-\mathrm{T}_{1}$ : Didactic proposal which incorporates concept maps and $\mathrm{V}$ diagrams.

$-\mathrm{T}_{2}$ : Teaching and learning program based on problem-solving guides.

\section{Population and Sample}

The population consisted of all first-year students of Civil Engineering at the University of Bío Bío. The sample is composed by first-year students participating in the modular course Physics I (Module I and II), issued by the Department of Physics at the same university.

The sample consists of 74 students in their first year of study in Civil Engineering at the University of Bío Bío, Concepción, of which $20.3 \%$ were female and $79.7 \%$ male. The show is simple random type, where all subjects have the same probability to be part of the experimental or control group, a product that students enrol via the Internet and each section has limited capacity.

\section{Data Collection Instrument}

A) Interest and Creative Performance Questionnaire (ICPQ): test that identifies creative abilities of students. It has 60 items grouped into five criteria:

1). Creativity in Art and Writing (AW): high scores denote taste for the arts, legends, poetry and music. The low score does not show interest in the arts.

2). Challenge and Inventive (ChI): high scores denote taste for risk. These subjects like difficult tasks, invent and think of new ideas. The low scorers tend to prefer the inconstancy and tasks easier and less risky.

3). Confidence and Independence (CI): high scoring subjects find school tasks easy, believe they have good ideas. Are independent with respect to the peer pressure and like to try new opportunities. The low score have a poor self-image and consider it important to be like others.

4). Imagination (I): high scores detect curiosity subjects, they like to ask questions, loneliness and travel; also has new and imaginative ideas. The low scoring individuals are more realistic, literal and less curious.

5). Varied Interests (VI): High scoring individuals has many hobbies and interest in drama, literature, life in other countries, the past, the future, and many other topics. The low-scoring have few interests and hobbies.

The values obtained through the Cronbach Alpha test for the validity of the instrument are: Creativity in Art and Writing: $\alpha$ $=.832$; Challenge and Inventive: $\alpha=.713$; Confidence and Independence: $\alpha=.694$; Imagination: $\alpha=.735$; Varied Interests: $\alpha=0.7$. Estimation of reliability for the total test: $\alpha=0.9$.B)

B) Academic performance was measured by a test, the validity of content is ensured to have been built by experts. This docu- 
ment is designed to assess the following content: kinematics in one and two dimensions and Newton dynamics.

\section{Data Analysis}

Data analysis is performed by non-parametric statistics using descriptive and univariate analysis via graphs, and the study of multiple correspondence between the variables involved. The results obtained in the pre and post test, and test scores are analyzed through Mc-Neman and Mann-Whitney test.

\section{Methodology in the Classroom}

The intervention mechanisms in the classroom are focused on solving conceptual questions using concept maps as a previous activity to solving problems through Gowin's V diagram.

The Figure 1 shows an example of a map of concepts, developed to respond a question, through connecting two or more concepts in words or linking phrases, in order to generate proposals, and identifying the hierarchy of concepts. In this situation the objective is to solve the following question: What is the relationship between mechanical work and mechanical energy of a system?

The Figure 2 shows the solution of a problem by Gowin's V diagram. In it you can see how the principles and concepts, belonging to conceptual theoretical domain interact with the methodological elements (transformations) with the aim of responding (assertion of knowledge) the question or issue that emerges from the event.

\section{Results}

\section{Results of Pre and Post Test ICPQ}

The results of pre and post test performed for creativity to both groups are displayed in Figures $\mathbf{3}$ and $\mathbf{4}$.
Figure 3 shows that both groups get similar results before starting the course. We do not find significant differences for any section by Mann-Whitney test. So, it is possible to note that the sample is homogeneous in relation to levels of creativity, therefore, any differences in post-test measurement, will be the product of the methodology used.

The comparison of both groups to post-test results (Figure 4) by the Mann-Whitney statistical test, indicates that there are significant differences at $95 \%$, in favour of the experimental group in dimension Varied Interests (IV), $p=0.0449$. However, these differences are not identifiable in the other dimensions.

Figures 5 and 6 shows the percentage of students in the experimental and control group, which scores in pre and post-test

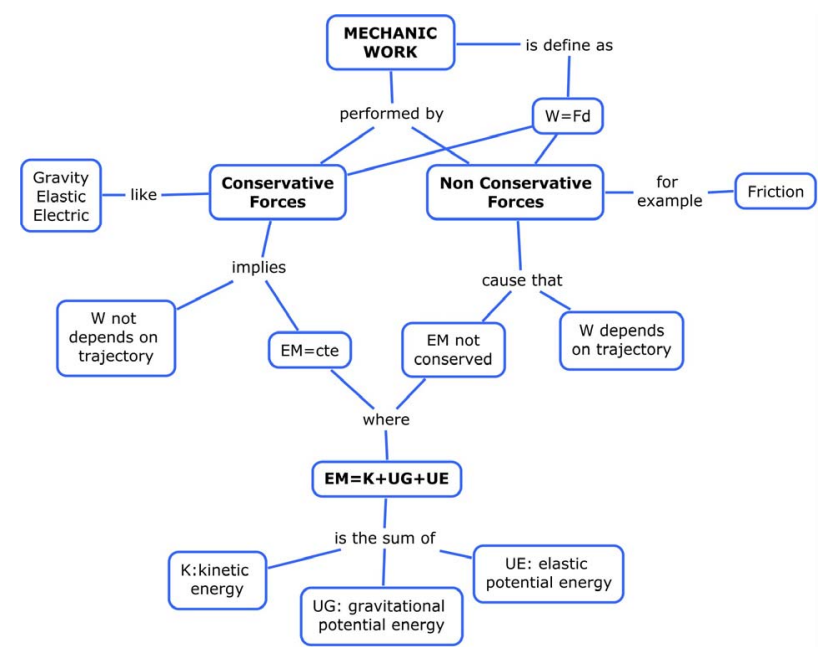

Figure 1.

Concept map drawn to explain the relationship between work and mechanical energy.

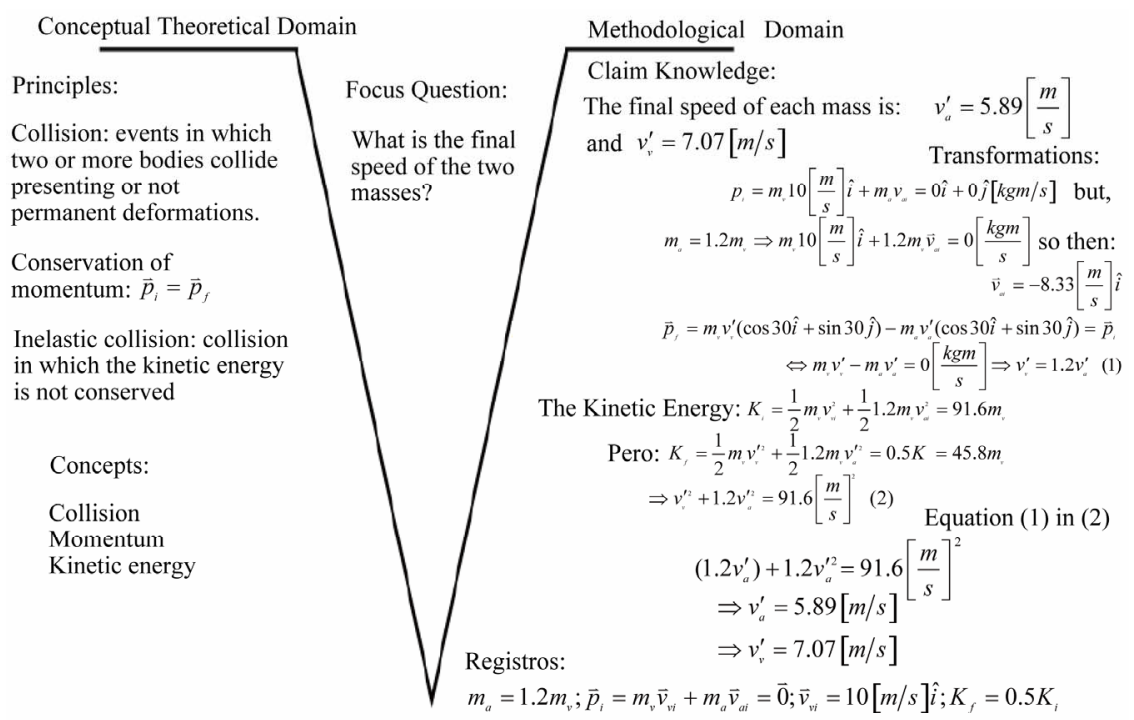

Event: The blue mass is $20 \%$ greater than the mass of green. Before the collision, the masses are close to equal but opposite momentum. Consider that the speed of the green mass is $10[\mathrm{~m} / \mathrm{s}]$ before the crash, and also half the kinetic energy lost during this.

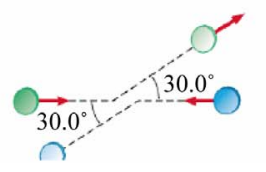

Figure 2.

Problem solved by V synthesized diagram and its components. 


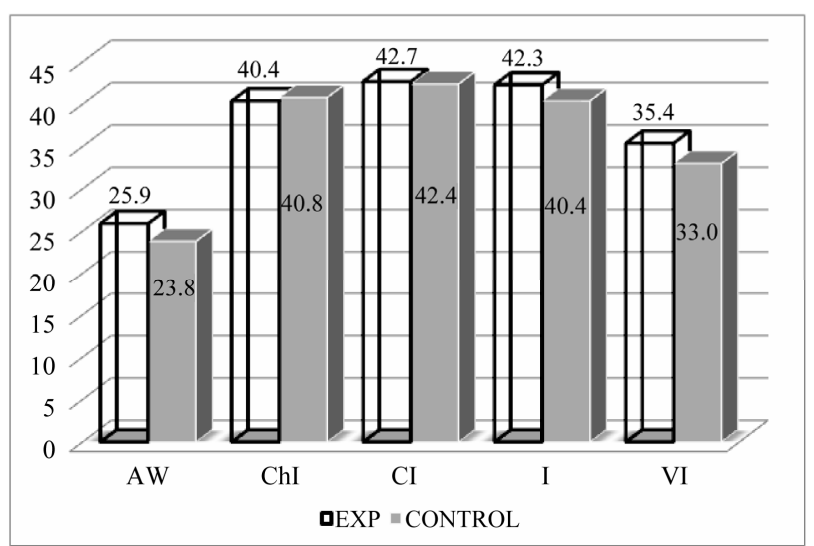

Figure 3.

Average score obtained in pre test for the experimental and control groups.

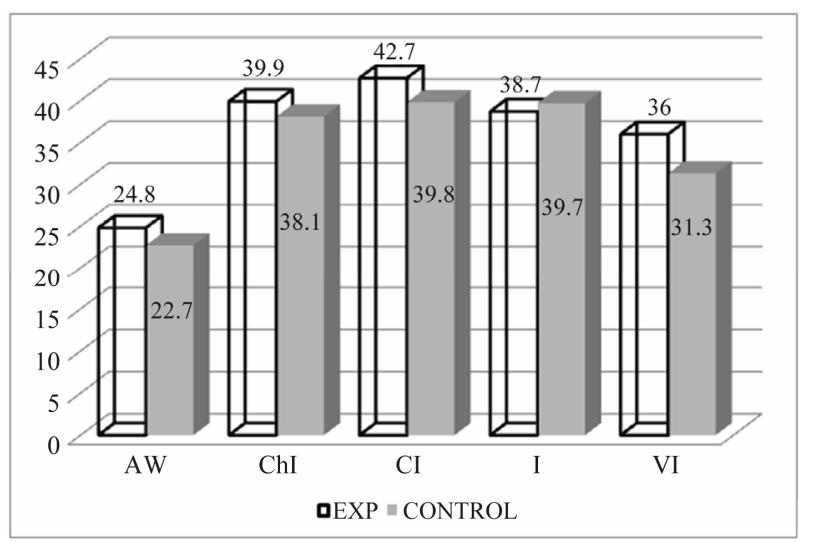

Figure 4.

Average score obtained in post test for the experimental and control groups.

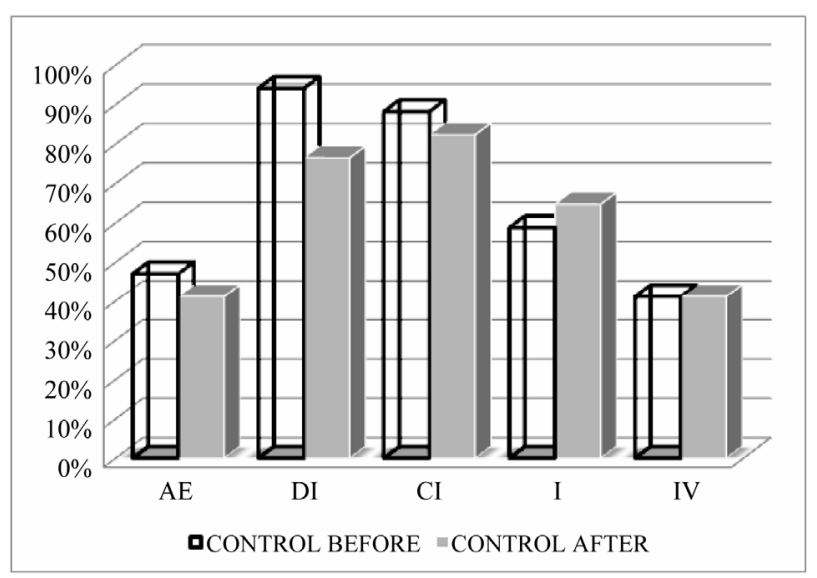

Figure 5.

Percentage of students in control group, with normal and high levels in pre test of creativity.

were classified in normal and high categories.

Although the analysis of the results of the post test, using the McNemar test revealed no significant differences at $95 \%$, in Figure 6 it is possible to identify an improvement in the percentage of students achieving scores between normal and high

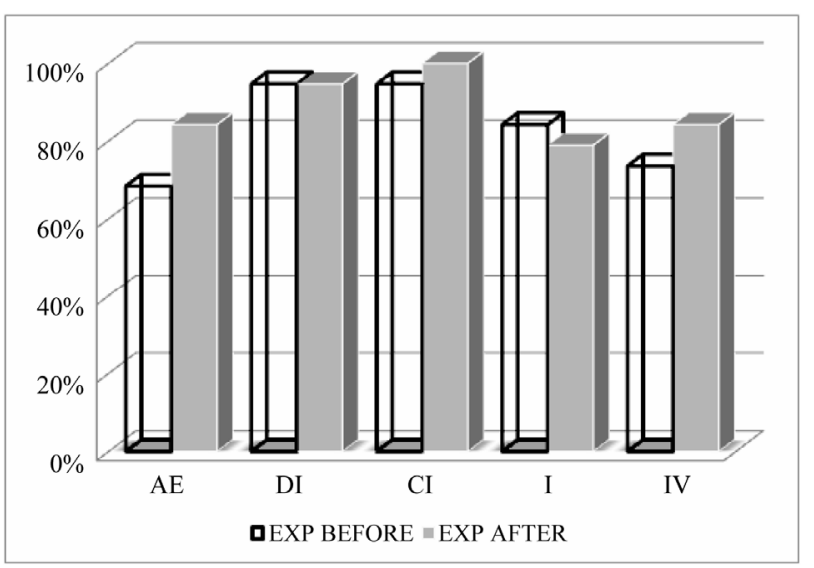

Figure 6.

Percentage of students in experimental group, with normal and high levels in pre test of creativity.

ranges, in Arts and Writing (AW), Confidence and Independence (CI) and Varied Interest (VI), contrary to what happens in the control group (Figure 5), where these percentages decrease, except in the imagination factor (I).

\section{Academic Performance}

Through an exam constructed by experts in physics, we evaluated the performance of students intervened. The Figure 7 shows the percentage of students that scored 4.0 or above in the test, which involves the approval of the subject.

In addition, it is confirmed through the statistical result of the Mann-Whitney test, which delivers a value $\mathrm{p}=.0035$, showing significant differences to $99 \%$, in favour of the experimental group.

\section{Multiple Correspondence Analysis: Levels of Creativity and Academic Performance}

In order to determine to what extent the categories of creativity influence student performance, Figure 8 shows two dimensions ( 1 and 2 ) of the multiple correspondence analysis developed for these variables.

By identifying the quadrants of the Figure 8, you can understand what are the variables that explain the approval (QUAL: A) and failure (QUAL: F) in the experimental group. The approval, located in the first quadrant, would be explained in a $65.28 \%$ by high scores on Imagination (I) and Confidence and Independence (CI). While in the third quadrant are located the variables that explain with the same percentage the failure, which correspond to low scores on Imagination (I) and Confidence and Independence (CI).

Figure 9 corresponds to the dimension 1 and 3 of the multiple correspondence analysis between the previous variables. This side explains in a $57.89 \%$ the relationship between the categories of creativity and academic performance.

In Figure 9 we see that the approval (QUAL: A) is located in the fourth quadrant, so that high scores on Challenge and Inventive $(\mathrm{ChI})$ and Confidence and Independence $(\mathrm{CI})$, will explain it at a $57.89 \%$. Accordingly, the disapproval (QUAL: F), would be predicted by the same percentage by low scores on the same variables.

As high scores on the variable Confidence and Independence 


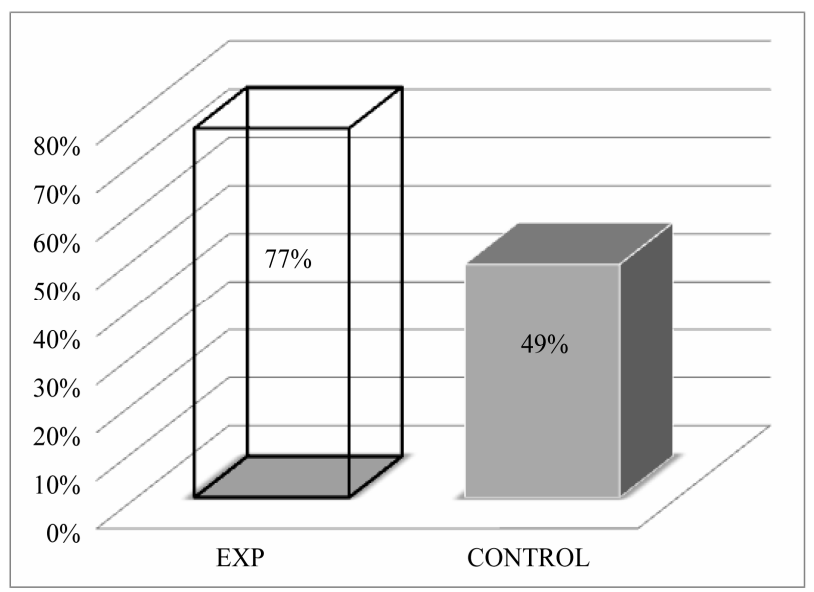

Figure 7.

Percentage of students who passed the test in experimental and control groups.

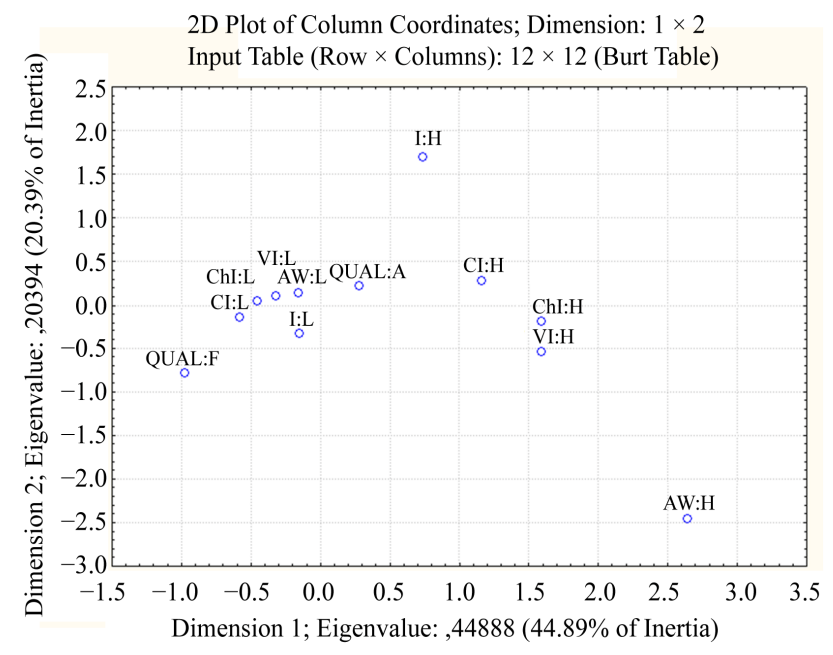

Figure 8.

Multiple correspondence analysis between scores in the post creativity test and academic performance.

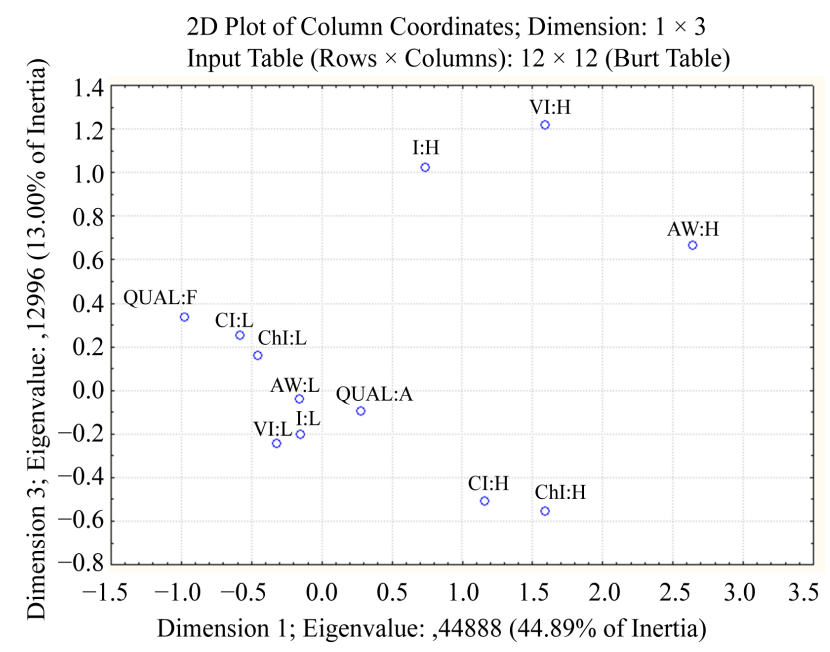

Figure 9.

Multiple correspondence analysis between scores in the post creativity test and academic performance. Dimensions 1 and 3.
(CI) appear as one element-related to the approval in all three dimensions, is declared now, that academic success can be explained in a $78.28 \%$ by these high scores.

\section{Discussions}

The relationship between the use of Gowin's V with concept maps and the development of creativity is still an incipient research problem. In this sense, this empirical study is a breakthrough for future research in order to gather evidence in this line of work. By the MCA it has been established creative profile and model predictor of academic success of engineering students newly admitted, depending on the dimensions of creative thinking. Although the results reported sufficient evidence to affirm the existence of a positive relationship between the intervention on the physics courses (Gowin's V and Concept Maps) and the development of creative thinking in an academic semester, it is not possible to establish categorical judgments given the large number of variables involved. Certainly the development of cognitive skills related to creative thinking requires consideration the speaking time, because this heavily contributes to the occurrence of this positive relationship, in addition to an intervention by Gowin's $\mathrm{V}$ and concept maps in a larger number of courses simultaneously. Consequently, it follows that any program aimed at developing creative skills in higher education should consider a methodological renewal and intervention time.

Our results indicate that the proposed methodological renovation based learning on concept maps and Gowin's V diagram to address the contents of Physics I with Civil Engineering students, can promote the construction of knowledge and some characteristics of creative thinking. It also promotes academic success as students from the experimental group obtained higher scores. The effectiveness of the V-based learning and concept maps can be seen in students' ability to perceive problems from different directions, which opens the range of possible solutions, which can turn out to be original and creative for students, even when it is not in a wider context. This mental flexibility affects both academically and in their future careers, where problem solving requires imagination, originality and an appropriate collaborative climate to achieve the solution. This is creative thinking's basis and it is helpful to understand the relationship between science, society and the environment.

The results also show that it is possible to develop creative thinking from the students in their own courses, through the presentation of problems or problematic situations that require different thinking and analysis for solution. In the proposed resolution of problems through Gowin's V and concept mapping, specifically in the search phase, selection and pooling of information develops creative thinking. This also requires other skills such as critical and analytical thinking, which allow us to interpret, analyze and evaluate each of the alternatives, and select the best proposals based on established criteria. In this context, it can be stated that this proposal's implementation for the development of creative thinking in more courses throughout the student's curriculum, should encourage open-mindedness, flexibility, verbal fluency and originality in the students, which would lead to be able to generate more than one alternative solution to a problem or situation.

Consequently, the academic activity should create learning environments that provide opportunities to develop creativity in the classroom, generating thinking flexibility, especially in the 
early college courses, which are less likely to have this opening problematic, because sometimes characterized by constant repetition of activities and procedures, which influences the quality of the productions generated by students (Sanchez, 2012). Thus, from the early years students will develop: thought independence, use and versatility in finding information, favoring observation capacities and establish relations in problem solving and making decisions.

Based on these experiences, it is concluded that progress is being made in the level of creativity and inventiveness of the students through the use of the Gowin's V and concept maps as a medium for problem solving and knowledge building, both used as active learning methods that stimulate and support creativity and inventiveness. Although this proposal has not significantly influenced in all studied categories of creativity, it is thought that extending the time of the intervention and the number of courses in which it is implemented, the results will be better.

\section{Conclusion}

The first comment that comes from the analysis of the results is to point out that the use of concept maps and Gowin's V diagrams as tools for analysis and problem solving, promotes academic performance and success.

While ICPQ post test results do not allow establishing significant differences in pre-test, the Figure 6 shows a tendency of developments in Art and Writing dimensions, Confidence and Independence, and Varied Interest approaching to high scores. Whereas working time has not exceeded 3 months, which is not enough to change these cognitive skills. It opens the possibility that the incorporation of these heuristic devices within broader academic period, will uncover the appropriate changes in creativity levels and thus enhance the ability to transfer and promote meaningful learning.

Considering that all groups were evaluated constantly, at the same moment and with the same instrument, the exercise to facilitate the content and not delay it becomes a problem, since the processes of reflection and negotiation of meaning require longer periods of time than to resolve exercises in a mechanic way. Consequently, the introduction of heuristic devices in the classroom involves an increase in the time to teach and learn the content, which constitutes an advantage for groups that work mechanically, considering the simultaneous evaluations.

Producing the analysis of the categories of creativity and its relationship to academic performance (Figures 8 and 9), it is possible to note that scores high on Confidence and Independence, explain on a $78.28 \%$ approval note, exceeding high scores in Imagination, with $65.25 \%$, and in defiance and ingenuity, with $57.89 \%$. For its part, the reprobation would be explained by lower results in the same categories and respecting the ratio percentages. In summary, academic success is highly related to the creative capabilities that each student shows.

The high correlation between some dimensions of creativity and academic success, indicates the importance of this cognitive variable (creativity) in the teaching and learning science, so it is urgent to consider it at the moment of building intervention methods in the classroom. Moreover, despite of the information obtained product of the analysis, it should further deepen the role played by the creative skills in learning, as well as in the future academic and professional students.

It is noteworthy that the type of work, based on the active participation of students in front of the construction of concept maps and $\mathrm{V}$ diagrams, has allowed building an atmosphere of collaboration and dialogue in the classroom, which has facilitated reflection and negotiation of meanings. By producing this, students have maintained a positive attitude in the face of new information and solving problems.

\section{Acknowledgements}

This research is made possible through funding obtained from the research project FONDECYT $\mathrm{N}^{\circ} 1120767$ entitled "Towards a program to develop cognitive strategies from physics."

\section{REFERENCES}

Ausubel, D., Novak, J., \& Hanesian, H. (1983). Psicología educativa. Un punto de vista cognoscitivo, Ed. Trillas, México.

Campanario, J. M. (2000). El desarrollo de la metacognición en el aprendizaje de las ciencias: Estrategias para el profesor y actividades orientadas al alumno. Enseñanza de las Ciencias, 18, 369-380.

Carpio, C., Canales, C., Morales, G., Arroyo, R., \& Silva, H. (2007). Inteligencia, creatividad y desarrollo psicológico. Acta Colombiana de Psicología, 10, 41-50.

Chrobak, R. (2008). Una enseñanza creativa, para obtener aprendizajes creativos. Cuadernos FHyCS-UNJu, 35, 115-129.

Cohen, L., \& Manion, L. (1990). Métodos de investigación educativa, pp. 10-100, La muralla S. A. España.

Donolo, D., \& Rinaudo, M. C. (2008). Perspectivas y experiencias creativas para estudiantes universitarios. Cuadernos de FHyCS-UNJu, 35, 91-113.

Esquivias, S. M. T., \& Muriá, V. I. (2001). Una evaluación de la creatividad en la Educación Primaria. [en línea]. Revista Digital Universitaria. http://www.revista.unam.mx/vol.1/num3/art1/

Flores, J., Caballero, M. C., \& Moreira, M. A. (2009). El laboratorio en la enseñanza de las ciencias: Una visión integral en este complejo ambiente de aprendizaje. Revista de Investigación, 68, 75-111.

García, P., Insausti, M. J., \& Merino, M. (2003). Evaluación de los trabajo prácticos mediante diagramas V. Revista Electrónica de Enseñanza de las Ciencias, 2, 45-57.

Gil, J., \& Solano, F. (2011) El uso de la Vee epistemológica en la resolución de problemas en Física. XXXIII Reunión Bienal de Real Sociedad Española de Física.

López, M. O. (2008). Enseñanza creatividad. El espacio educativo. Cuadernos FHyCS-Universidad de Jujuy, 35, 31-40.

López, S., Angela, E., \& Solano, I. (2011). Modelación computacional apoyada en el uso del diagrama $\mathrm{V}$ para el aprendizaje de conceptos de dinámica newtoniana. Revista Electrónica de Enseñanza de las Ciencias, 10, 202-226.

Moreira, M. A. (1997). Aprendizaje significativo: Un concepto subyacente. Burgos: Actas del Encuentro Internacional sobre el Aprendizaje Significativo.

Moreira, M. A. (1998). Mapas conceptuales y aprendizaje significativo en ciencias. Cadernos do Aplicação, 11, 143-156.

Moreira, M. A. (2006). Mapas conceptuales y diagramas V. Porto Alegre: Editorial del Autor.

Moreira, M. A. (2007). Diagramas V y aprendizaje significativo. Revista Chilena de Educación Científica, 6.

Otero, M. R., Greca, I. M., \& Lang da Silveira, F. (2003). Imágenes visuales en el aula y rendimiento escolar en Física: un estudio comparativo. Revista Electrónica de Enseñanza de las Ciencias, 2, $1-30$.

Ramírez, M., \& Sanabria, I. (2004). El mapa conceptual como elemento fundamental en el proceso de enseñanza-aprendizaje de la física a nivel universitario. Proceedings of the First International Conference on Concept Mapping, Pamplona.

Perales, F. J. (2006). Uso (y abuso) de la imagen en la enseñanza de las 


\section{J. A. P. NEIRA, I. R. S. SOTO}

ciencias. Enseñanza de las Ciencias, 24, 13-30.

Perales, F. J. (2008). La imagen en la enseñanza de las ciencias: algunos resultados de investigación en la Universidad de Granada, España. Formación Universitaria, 1.

Reyes, M. (2003). Las estrategias creativas como factor de cambio en la actitud del docente para la enseñanza de la matemática. Sapiens, 4.

Sanabria, I., Ramirez, M., \& Aspée, M. (2006). Una estrategia instruccional para el laboratorio de Física I usando la "V de Gowin". Revista Mexicana de Física, 52, 22-25.

Sánchez, I. (2012). Evaluación de una Renovación Metodológica para un Aprendizaje Significativo de la Física. Revista Formación Universitaria, 5, 51-65.

http://dx.doi.org/10.4067/S0718-50062012000500006

Silva, E. (2005). Estrategias constructivistas en el aprendizaje significativo: su relación con la creatividad. Revista Venezolana de Ciencias Sociales, 9, 178-203.

Torre, S. (1993). Creatividad plural: Sendas para indagar sus múltiples perspectivas. Promociones y Publicaciones Universitarias. Barcelona. 